\title{
Effects of Small Rodent and Large Mammal Exclusion on Seedling Recruitment in Costa Rica ${ }^{1}$
}

\author{
Elizabeth A. DeMattia², Beverly J. Rathcke \\ Department of Ecology and Evolutionary Biology, University of Michigan, 830 North University, Ann Arbor, Michigan 48109-1048, U.S.A.
}

\author{
Lisa M. Curran
}

Yale School of Forestry and Environmental Studies, 370 Prospect Street, New Haven, Connecticut 06517, U.S.A.

\author{
Reinaldo Aguilar and Orlando Vargas
}

Organization for Tropical Studies, La Selva Biological Station, Apartado 676-2050, San Pedro, Costa Rica

\begin{abstract}
We examined whether the experimental exclusion of large mammalian and small rodent seed predators had differing effects on seedling recruitment under natural seed rain conditions. In both primary and late-successional secondary forested areas, exclosure experiments using natural seed densities were designed to assess seedling recruitment. To assess the differences in seedling recruitment, we monitored three exclosure treatments $(1.2 \mathrm{~m}$ radius $/ 1.5 \mathrm{~m}$ height) in two forest types (primary vs. late-successional secondary forest): (1) fenced exclosures that excluded large mammals; (2) fenced exclosures that excluded both large and small mammals; and (3) open controls. Within each exclosure treatment, we marked and identified all seedlings at the beginning of the experiment (February 2001), followed the marked seedlings' fate for a year, and then marked and identified all new seedlings after a year. Two preliminary findings were generated from these data: for some tree species, small rodents and large mammals have differential effects on seedling recruitment, and the effect of excluding mammals did not differ with habitat type (primary vs. late-successional secondary forest). These preliminary results highlight the need to examine further how the effects of small rodent and large mammal exclusion may affect species-specific seed predation and seedling recruitment in a variety of habitat/land use types (e.g., primary forest, late-successional forest, and early-successional forest).
\end{abstract}

\section{RESUMEN}

Nuestra investigación comparó los efectos de roedores pequeños y de mamíferos grandes en la regeneración de plántulas en bosques primarios y secundarios. Nuestros experimentos utilizaron las densidades naturales de la semilla para entender la regeneración de plántulas. Para medir las diferencias en la regeneración de plántulas, controlamos tres áreas de exclusión (1.2 radio M/1.5 M alta) en dos tipos de bosque (primario contra el bosque secundario): (1) jaulas cercadas que excluyeron mamíferos grandes; (2) jaulas cercadas que excluyeron ambos mamíferos grandes y pequeños; y (3) los controles abiertos. Dentro de cada área de exclusión, marcamos e identificamos todas las plántulas al principio del experimento (febrero 2001), seguimos el destino de las plántulas marcadas por un año, y al final marcamos e identificamos todos las plántulas nuevas después de un año. Esta investigación produjo dos hallazgos preliminares: para algunas especies de árboles, roedores pequeños y mamíferos grandes tienen efectos diferentes en la regeneración de plántulas; y no hubo diferencias entre el efecto de exclusión de mamíferos en los dos tipos de bosque (bosque primario y bosque secundario). Estos resultados preliminares indican que más estudios sobre los efectos de la exclusión de roedores pequeños y mamíferos grandes en la regeneración de plantas/árboles dentro de los bosques primarios y los bosques secundarios.

Key words: Corcovado National Park; exclosures; microsite variation; Perebea hispidula; Pouteria sp.; tropical forest; Trophis racemosa.

SEEDLING RECRUITMENT FROM A GERMINATED SEED is one of the largest bottlenecks for the regeneration of tropical trees (Hubbell et al. 1999, Harms et al. 2000). In the Neotropics, post-dispersal seed predation by terrestrial mammals is an important mechanism influencing the seedling recruitment bottleneck (Janzen 1971; DeSteven \& Putz 1984; Sork 1987; Adler \& Seamon 1991; Forget 1993, 1994; Hammond 1995; Notman et al. 1996; Asquith et al. 1997, 1999; Adler \& Kestell 1998; Forget et al. 1999; Lambert \& Adler 2000; Wright et al. 2000; Altrichter et al. 2001; Brewer \& Webb 2001; Roldán \& Simonetti 2001; Wright \& Duber 2001; Guariguata et al. 2002; Silman et al. 2003; DeMattia et al. 2004). Seed predation studies have highlighted the importance of mammalian seed predation; however, most have focused on

${ }^{1}$ Received 9 July 2004; revision accepted 1 June 2005.

${ }^{2}$ Corresponding author; current address: The School for Field Studies, 10 Federal St., Salem MA 01970, U.S.A.; e-mail: ldemattia@fieldstudies.org large-bodied seed predators (e.g., Dasyprocta punctata, Pecari tajacu, Tayassu pecari, and Agouti paca). Large-bodied seed predators can affect seedling recruitment negatively via seed predation and positively through dispersal (scatterhoarding). However, much less is known about the effects of other terrestrial mammalian seed predators, specifically small rodents (but see Adler \& Seamon 1991, Adler \& Kestell 1998, Lambert \& Adler 2000, Brewer \& Webb 2001, DeMattia et al. 2004). Because small rodents and large mammals have unique dietary preferences, home ranges, behavior, community structure, and population dynamics, the effects of small rodents on seedling recruitment cannot be inferred from the documented effects of larger-bodied seed predators.

Although most research on small rodent seed predation has focused on two species (Tomes' spiny rat: Proechimys semispinosus and forest spiny pocket mouse: Heteromys desmarestianus), tropical forests can support numerous rodent individuals and several 
sympatric species (Fleming 1970, 1973; Voss \& Emmons 1996; Reid 1997; DeMattia et al. 2004). Such diversity within terrestrial mammalian seed predators (small rodent communities and large mammals) can, theoretically, affect a wide range of plant species via seed predation and seedling recruitment. However, differences between the effects of Neotropical small rodents and large mammals on seedling recruitment have yet to be quantified within a sympatric community.

Understanding the effects of both large mammalian and small rodent seed predators on seedling recruitment is especially important given that mammal hunting and forest fragmentation differentially affect these two groups of seed predators. Hunting within Neotropical forests has severely decreased the populations of several large-bodied terrestrial mammalian seed predators such as T. pecari, P. tajacu, D. punctata, and A. paca (Reid 1997, Terborgh 1999, Carrillo et al. 2000, Wright et al. 2000, Roldán \& Simonetti 2001, Wright \& Duber 2001, Peres 2001, Naughton-Treves et al. 2003). In contrast to large-bodied seed predators, small rodents are largely ignored by hunters and are able to persist within the mosaic of primary forest, secondary forest, and cattle pasture. Moreover, during years of high abundances, they have high metabolic demands and thus impose strong seed predation pressures (Peres 2001, Jerozolimski \& Peres 2003, DeMattia 2004, DeMattia et al. 2004). Given these differences, this study aims to examine the individual roles of these two groups of seed predators within a forest community. We examined whether the experimental exclusion of large mammalian and small rodent seed predators had distinctive effects on seedling recruitment. In both primary and late-successional secondary forested areas, exclosure experiments using natural seed densities were designed to assess seedling recruitment and address the following questions:

(1) Do small rodent and large mammalian seed predators have similar effects on seedling recruitment? Specifically, will the exclusion of large mammals change the species-specific seedling recruitment?

(2) Does habitat (primary vs. secondary forest) affect small rodent and large mammalian seed predation pressures? Specifically, does the exclusion of large mammals and small rodents have similar effects across habitats? And, is seedling recruitment similar across habitats?

\section{METHODS}

Site DESCRIPTION.-Field studies were conducted at Sirena Biological Station, Corcovado National Park (CNP), Costa Rica $\left(8^{\circ} 28^{\prime} 49^{\prime \prime} \mathrm{N}, 83^{\circ} 35^{\prime} 22^{\prime \prime} \mathrm{W}\right)$. The region, described as tropical wet forest, receives $>5 \mathrm{~m}$ of rain annually with the majority of rain falling during the annual rainy season (August-December; Hartshorn 1983). The dry season extends from January through March with average rainfall ranging from 10 to $75 \mathrm{~mm}$ (Sirena station's data, Hartshorn 1983). As a result of the relatively large area (54,500 ha) and $30 \mathrm{yr}$ of National Park status at CNP, wildlife has been protected and CNP contains a community of post-dispersal, terrestrial seed predators that has not suffered from local extinctions.
This fully intact community of mammalian frugivores (including P. tajacu, T. pecari, D. punctata, and A. paca) provided an ideal study system for quantifying the dynamics of small rodent and large mammalian seed predation on seedling recruitment (DeMattia 2004).

Sirena Biological Station also has a land use history that allowed for the comparison of seedling recruitment in primary and latesecondary successional forests (sensu Richards 1952). Currently, the area contains both primary and late-secondary forest with canopies 30-70 m height. When the park was created in October 1975, approximately 10 percent of the park comprised farmsteads where the dominant activity was subsistence agriculture and cattle ranching (Phillips 1989). Because these farmstead areas were abandoned and allowed to undergo natural succession, these late-secondary forests are now $c a 30$ yr old. The demarcation of both primary and secondary forest habitats was determined using historical information, settlement maps, aerial infrared photographs (Phillips 1989), and ground-truthed tree censuses (DeMattia 2004). These data on adult tree diversity, coupled with historical land use information provided an accurate, fine-grained habitat typing for comparison of seedling recruitment in both secondary and primary forest habitats. While adult tree diversity differed significantly between the primary and the secondary forest habitats (DeMattia 2004), all terrestrial large mammalian seed predators were observed in both habitats (E. DeMattia, pers. obs.) and extensive small rodent trapping in both habitats showed similar diversity and abundance (DeMattia 2004).

EXCLOSURE EXPERIMENTS.-We indirectly isolated the effect of seed predation by different groups of terrestrial mammalian seed predators on the species-specific recruitment of canopy and subcanopy tree's seeds using exclosure experiments. To accomplish this, we established three exclosure treatments in the two forest types: (1) latesuccessional secondary forest habitat and (2) primary forest habitat. The first treatment ( $\mathrm{SR}=$ small rodent access) isolated small rodent effects by excluding large mammals. Large mammals were excluded using circular wire fencing $(1.2 \mathrm{~m}$ radius $/ 1.5 \mathrm{~m}$ height $)$ with an opening along the bottom edge $(10 \mathrm{~cm}$ height $)$ that allowed small rodent access. The second treatment was an open control that allowed both large mammal and small rodent access (LMSR $=$ large mammals and small rodent access). The third treatment (CLOSED = closed to all mammals) excluded small rodents and large mammals. Small rodents and large mammals were excluded using circular wire fencing ( $2 \mathrm{~m}$ radius $/ 1.5 \mathrm{~m}$ height) with plastic siding along the top edge (to prevent access by small rodents), a design that enabled access by insects and fungal spores, but did not alter the abiotic environment. This was an incomplete factorial design because it was not feasible to exclude small rodents without also excluding the large mammals.

Within both primary and secondary forest habitat, a total of 12 randomly separated "exclosure replicates" were monitored from February 2002 to February 2003 (24 exclosure replicates total; the distance between the secondary and the primary forested habitat was $>1 \mathrm{~km}$ ). To ensure independence among exclosure 
replicates, replicates were separated by at least $20 \mathrm{~m} \mathrm{(20} \mathrm{m} \mathrm{was}$ greater than the minimum home range estimates for small rodent species at CNP; DeMattia 2004). Each exclosure replicate had one open control (LMSR), one large mammal exclosure (SR), and one large mammal and small rodent exclosure (CLOSED). Within each exclosure treatment, we marked and identified all seedlings at the beginning of the experiment (BEFORE seedling countsFebruary 2001), followed the marked seedlings' fate for a year, and then marked and identified all new seedlings after a year (AFTER seedling counts-February 2002). All seedlings $\leq 2 \mathrm{~m}$ height were included in this study, and herbaceous understory plants were excluded.

We compared each species BEFORE and AFTER seedling counts and controlled for habitat and treatment. From this comparison, we examined whether a species had significantly more or fewer seedlings after a year. Fewer seedlings indicated that mortality factors affected the seedlings, whereas more seedlings indicated that recruitment ensued. By distinguishing mortality factors from recruitment, we discerned whether seedling mortality and recruitment were independent of taxon, treatment, and habitat.

DATA ANALYSIS.-Because we used natural seedfall densities, the number of seeds falling into exclosure treatments and the number of seedlings within the treatments was uneven and for some species, it was low (between 0 and 5 individuals). The total number of seedlings for each species (summed over all replicates) ranged from 0 to 30 individuals within a treatment and was not normally distributed across treatments and habitats. Therefore, we developed a randomization model to test for differences among treatments, species, and habitats.

We assessed whether BEFORE seedling counts (summation of replicates within a treatment) were significantly greater or less than AFTER seedling counts (summation of replicates within a treatment) using a randomization statistic based on the resampling protocol defined below. The randomization statistic tested the extent to which seedling mortality and recruitment were independent of taxon, treatment, and habitat (i.e., whether small rodents had a significant effect on seedling recruitment; whether the effect of small rodents on seedling recruitment differed from that of large mammals, and whether the effect was influenced by primary or secondary forest habitat). For each habitat and treatment, the BEFORE data were resampled 10,000 times (the resampling was subject to the constraint that the total number of seedlings BEFORE and AFTER remained the same for each simulated count); each time the number of species in the AFTER count was compared to the number resampled (simulated count). If the simulated count was greater than the observed value in $<500$ times per 10,000, the observed count was considered significantly high. Conversely, if the simulated count was less than the observed value in $<500$ times per 10,000, the observed count was considered significantly low. A significantly low seedling count indicated that mortality factors affected the seedlings, whereas a significantly high seedling count indicated that recruitment ensued (i.e., the seed was not consumed by a seed predator).

\section{RESULTS}

SPECIES-SPECIFIC PATTERNS OF SEEDLING RECRUITMENT.-A total of 22 seedling species were identified in the BEFORE species counts and monitored until the AFTER species counts [Capparis discolor Donn. Sm., Casearia corymbosa Kunth, Chrysochlamys glauca (Oerst., Planch., \& Triana) Hemsl., Clarisia racemosa Ruiz \& Pav., Croton schiedeanus Schltdl., Faramea occidentalis (L.) A. Rich., Genipa americana L., Guatteria amplifolia Triana \& Planch., Inga marginata Willd., Inga sapiondoides Willd., Ixora nicaraguensis Wernham, Macrocnemum roseum (Ruiz \& Pav.) Wedd., Mortoniodendron anispophyllum (Standl.) Standl. \& Steyerm, Nectandra hypoleuca Ámel, Nectandra sp., Ocotea ira Mez \& Pittier, Otoba novogranatensis Moldenke, Perebea hispidula Standl., Pseudolmedia spuria (Sw.) Griseb., Pterocarpus violaceus Vogel, Sorocea cufodontisii W. C. Burger, Trichilia septentrionalis C. DC., and Trophis racemosa (L.) Urb.]. In addition to those species that were present at the onset of the experiment, an additional five species recruited into CLOSED exclosure treatments (Brosimum costaricanum Liebm., Inga multijuga Benth., P. hispidula Standl., Pouteria sp., and Morphospecies 2), four species recruited into SR exclosures (C. racemosa Ruiz \& Pav., I. multijuga Benth., T. racemosa (L.) Urb., and Morphospecies 1), and two species recruited into the LMSR open controls (I. multijuga Benth. and Hirtella sp.).

In the secondary forest treatments, only one species showed a significant change in the number of seedlings, and the decrease only occurred in the LMSR open control treatment. $M$. roseum had significantly fewer seedlings in February 2002 than in February 2001 (Fig. 1). In addition, I. marginata displayed a trend toward slightly more seedlings in 2002 than in 2001 (Fig. 1).

In the primary forest treatments, significant increases in seedling numbers were observed only in the SR and CLOSED treatments, and a significant decrease in numbers was observed in the CLOSED treatment. In the SR treatment, T. racemosa had significantly more seedlings in 2002 than in 2001. In the CLOSED treatment, Pouteria sp. and P. hispidula had significantly more seedlings in 2002 than in 2001, and P. violaceus had significantly fewer seedlings in February 2002 than in 2001 (Fig. 2).

SMALL RODENTS AND LARGE MAMMALS AFFECT SEEDLING RECRUITMENT.-While the majority of species showed no effect of small rodents and large mammals on seedling recruitment, one species did have a significant difference in recruitment between the SR and the LMSR treatments, and two species recruited only into treatments that excluded all mammals. In secondary forest habitat, the four seedling species that were present in both the SR and the LMSR treatments (F. occidentalis, I. marginata, $O$. ira, and $I$. multijuga) had similar responses across treatments (i.e., in both treatments, the number of seedlings in the BEFORE count was statistically similar to the AFTER count; Fig. 1). In primary forest habitat, the three seedling species that were present in both the SR and the LMSR treatments ( $P$. violaceus, $I$. marginata, and $T$. septentrionalis) had similar responses across treatments (i.e., in both treatments the number of seedlings in the BEFORE count was statistically similar to the AFTER count; Fig. 2). However, one species, 

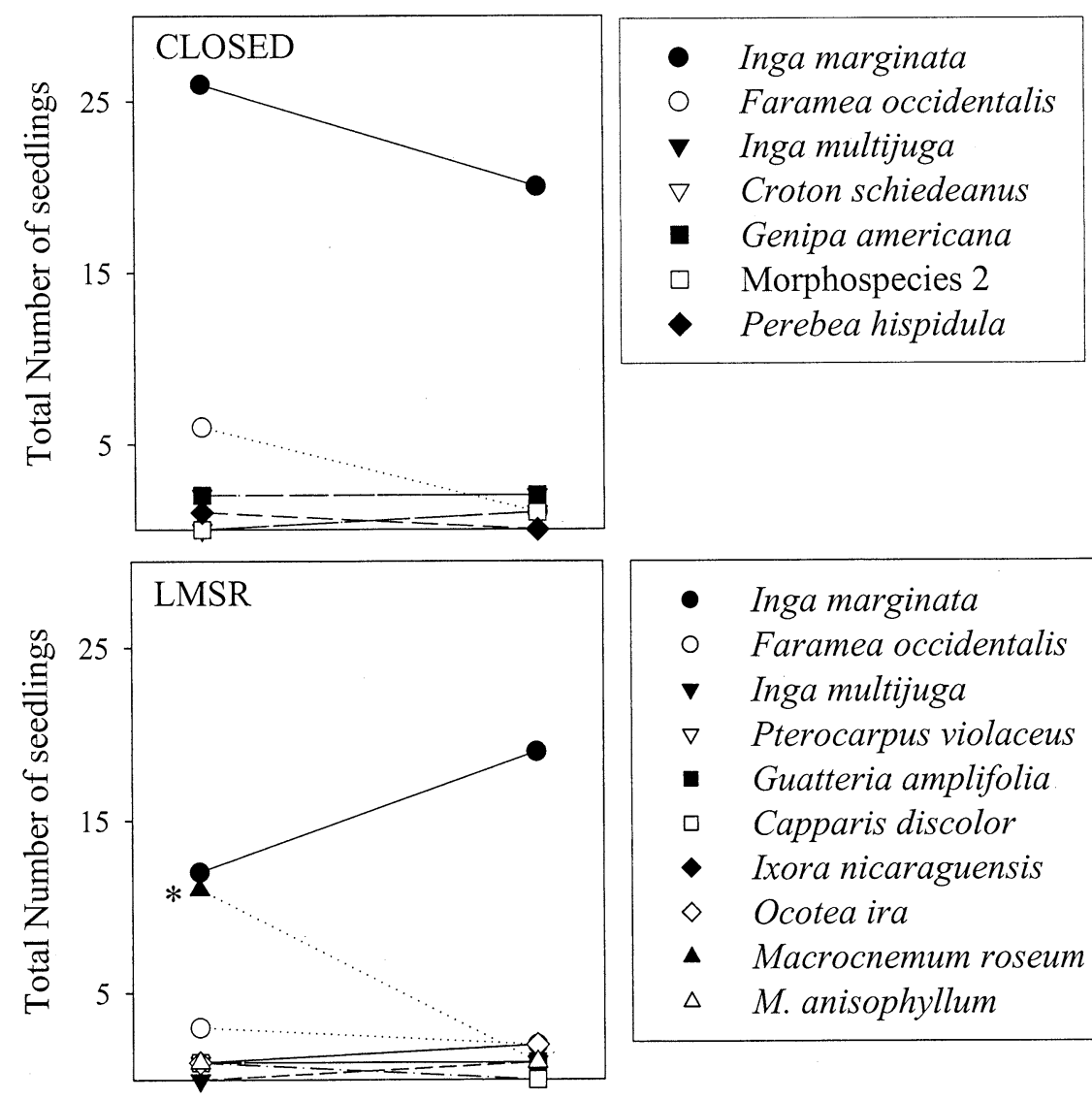

\begin{tabular}{|c|c|}
\hline & Inga marginata \\
\hline 0 & Faramea occidentalis \\
\hline$\nabla$ & Inga multijuga \\
\hline$\nabla$ & Pterocarpus violaceus \\
\hline & Guatteria amplifolia \\
\hline$\square$ & Capparis discolor \\
\hline$\bullet$ & Ixora nicaraguensis \\
\hline$\diamond$ & Ocotea ira \\
\hline$\Delta$ & Macrocnemum roseum \\
\hline$\Delta$ & M. anisophyllum \\
\hline
\end{tabular}

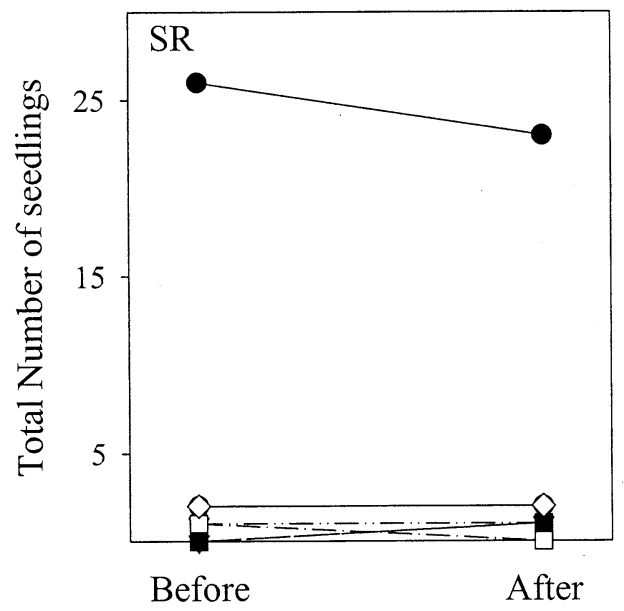

- Inga marginata

- Faramea occidentalis

- Inga multijuga

$\nabla \quad$ Chrysochlamys glauca

- Morphospecies 1

- Nectandra hypoleuca

- Nectandra sp

$\diamond \quad$ Ocotea ira

FIGURE 1. Number of seedlings in the BEFORE and AFTER secondary forest treatments (summed over all replicates). CLOSED = closed to mammals; LMSR $=$ large mammal and small rodent access; $S R=$ small rodent access. ${ }^{*}$ Indicate a significant change in the number of seedlings $\left({ }^{*} P<0.05 ;{ }^{* *} P<0.01\right)$.

T. racemosa, had significantly more seedlings in the AFTER counts for the SR treatment, but not in the LMSR treatment (Fig. 2).

Species present in both SR and CLOSED treatments showed similar responses in both treatments (Fig. 1, secondary forest: $F$. occidentalis, I. marginata, and I. multijuga; Fig. 2, primary forest: I. marginata and $P$. violaceus). In both treatments, and in both habitats, the number of seedlings in the BEFORE count was statistically similar to the AFTER count (Figs. 1 and 2). Interestingly, two species that were only present in the primary forest CLOSED treatment (P. hispidula and Pouteria sp.), exhibited a significant increase in the number of seedlings.

DIFFERENCES IN HABITAT.-When comparing habitats, only $I$. marginata occurred in all treatments in both habitats, and seedling recruitment did not differ significantly between habitats (Fig. 3). 

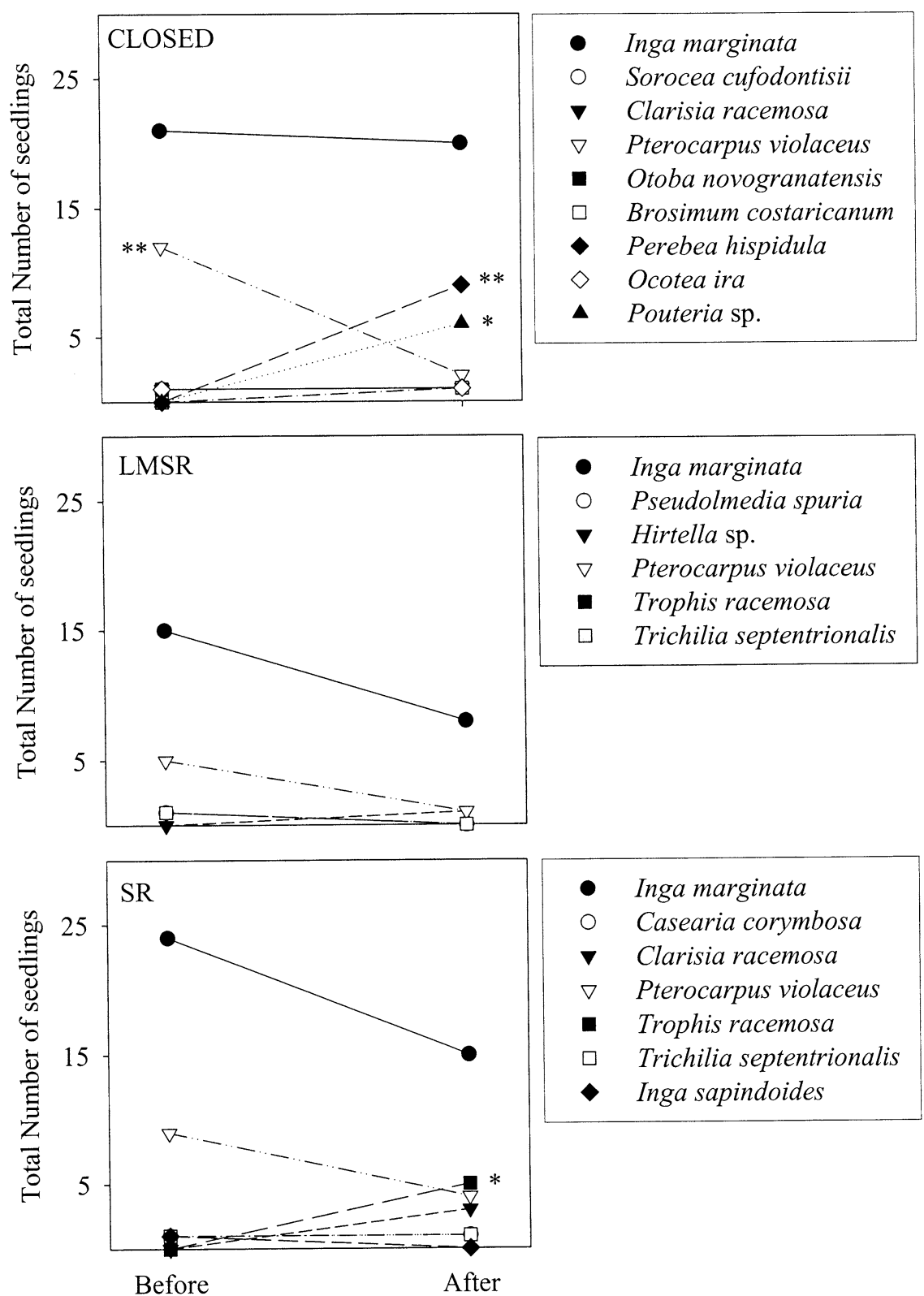

- Inga marginata

- Casearia corymbosa

- Clarisia racemosa

$\nabla \quad$ Pterocarpus violaceus

- Trophis racemosa

$\square \quad$ Trichilia septentrionalis

- Inga sapindoides

FIGURE 2. Number of seedlings in the BEFORE and AFTER primary forest treatments (summed over all replicates). CLOSED $=$ closed to mammals; LMSR $=$ large mammal and small rodent access; $\mathrm{SR}=$ small rodent access. ${ }^{*}$ Indicate a significant change in the number of seedlings $\left({ }^{*} P<0.05 ;{ }^{* *} P<0.01\right)$.

Another species, $P$. violaceous, was present in the LMSR treatment in both habitats, and also had similar recruitment patterns between habitats.

\section{DISCUSSION}

This seminatural experiment produced two preliminary findings: (1) for some tree species, it appears that small rodents and large mammals affect seedling recruitment and (2) at this site, the effect of excluding mammals did not differ significantly with habitat type (primary vs. late-successional secondary forest).
EFFECT OF SMALL RODENTS AND LARGE MAMMALS ON SEEDLING RECRUITMENT.- While the majority of species showed no effect of small rodents and large mammals on seedling recruitment, three species (T. racemosa, Pouteria sp., and P. hispidula) in primary forest were affected by mammalian exclusion (both small rodents and large mammals). Significant increases in recruitment for Pouteria sp. and $P$. hispidula occurred only in exclosure treatments where large mammals and small rodents were excluded. This result suggests that mammalian seed predators (small rodents and/or large mammals) have significant negative effects on seedling recruitment for these species. For T. racemosa, an increase in seedling recruitment was evident only in the SR treatment and not in the LMSR 


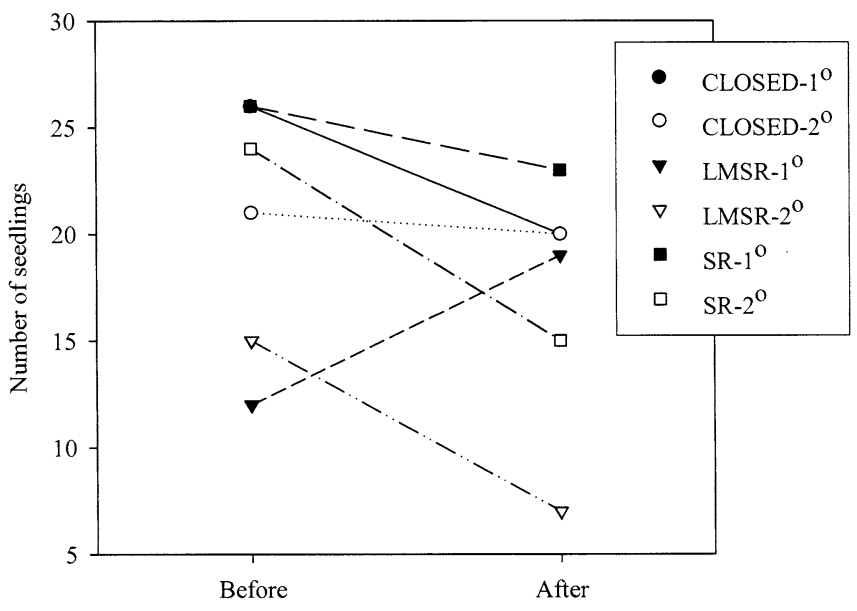

FIGURE 3. Number of Inga marginata seedlings in the BEFORE and AFTER primary and secondary forest treatments (summed over all replicates). CLOSED $=$ closed to mammals; LMSR = large mammal and small rodent access; $\mathrm{SR}=$ small rodent access. There were no significant differences between the before and the after counts for any of the treatments.

treatment. Thus, large mammals were the main seed predator for T. racemosa and/or small rodents scatterhoarded T. racemosa seeds into the SR treatment. The positive benefit of scatterhoarding from small rodents combined with the protection from the negative seed predation by large mammals could have allowed recruitment to ensue. Because this is a seminatural experiment with natural seed densities, we did not control the number and type of seeds falling into each treatment. Therefore, it is impossible to distinguish which group of seed predators was the most influential. Neither Pouteria sp. nor $P$. hispidula were present in the SR treatment, and $T$. racemosa was not present in the CLOSED treatment. Therefore, the increase in recruitment when small rodents were excluded in the CLOSED treatment cannot be definitively compared to the SR and LMSR treatments. These results suggest, however, that excluding terrestrial mammalian seed predators may increase seedling recruitment for some species, and provide preliminary evidence that small rodents and large mammals may have differential effects on seedling recruitment.

Preliminary evidence supporting the hypothesis that small rodents and large mammals may have differential effects on seedling recruitment can be found with the patterns of $B$. costaricanum and $C$. racemosa. In primary forest, $B$. costaricanum recruited only into exclosures where small rodents and large mammals were excluded (CLOSED) and C. racemosa recruited into both the LMSR treatment and the SR treatment where only large mammals were excluded. Concurrent research at CNP (DeMattia et al. 2004) demonstrated that small rodent seed predators have significant negative effects on both B. costaricanum and C. racemosa, and for these two species, the effects of small rodent seed predators differed from large mammals. Due to the heterogeneity of seedfall and low numbers of seedlings within primary forest, the significance of such observations could not be determined. These results do suggest, however, that large mammals and small rodents may impose limitations on seedling recruitment and provide a possibly starting point for future seedling recruitment experiments.

EFFECT OF HABITAT TYPE.-At this site, the effect of excluding mammals did not differ significantly with habitat type. For seedling species present in both forest types (I. marginata and $P$. violaceus), seedling recruitment patterns were statistically similar between forest types and treatments. However, with all species combined, and for all treatments, greater numbers of seedling species recruited into primary vs. late-successional secondary forest habitats, and the only significant increases in seedling recruitment, after the exclusion of mammals, occurred within primary forest (P. hispidula, Pouteria sp., and $T$. racemosa). This result could have resulted because the terrestrial seed predator communities differed by habitat type, and/or seed input differed between forest types. Concurrent research at CNP found that small rodent communities within the primary forest and secondary forest habitats at CNP do not differ (DeMattia et al. 2004), large mammalian seed predators have been observed in both habitats (E. DeMattia, pers. obs.), and seed predation pressures (by small rodents and large mammals) are similar across habitats (DeMattia et al. 2004). The difference between primary and secondary forest recruitment is likely a consequence of greater adult canopy tree diversity and greater seed rain diversity within the primary forest as compared to secondary forest. Such difference would be best determined through seed rain data; however, the seed rain component of this experimental design suffered from logistical and mechanical difficulties. In addition, seed rain data would assist in distinguishing whether seedling recruitment at this site is more predator-limited or microsite-limited (Crawley 2000). Therefore, future exclosure experiments should also monitor seed input.

For some species, mammalian seed predation may not be the primary driver affecting seedling recruitment. However, for other species mammalian seed predation does influence seed predation, and this exclosure study provides preliminary evidence that small rodents, in addition to large mammals, may positively (via scatterhoarding into favorable microsites) and negatively (via seed destruction) affect seedling recruitment. Further research should focus on distinguishing how these mammalian seed predators differ in their effects on seedling recruitment. As tropical forests become increasingly fragmented and hunting impacts more widespread, small rodents may become the only remaining group of terrestrial mammalian seed predators that remains intact. As the only intact group of mammalian seed predators within hunted and fragmented forests, small rodents may make a larger relative contribution to total seed predation and seedling recruitment. Therefore, understanding the species-specific roles that large mammals and small rodents play in seedling recruitment is critical to predicting the effects of anthropogenic alterations in tropical forest dynamics.

\section{ACKNOWLEDGMENTS}

We thank the Area de Conservacion de Osa (ACOSA), Ministerio de Recursos Naturales, Energia, Y Minas, Corcovado National 
Park, and CNP guards - P. Valverde, P. Aleman, and E. Gonzalesfor research sponsorship. B. Munson, L. Buis-Kelley, A. Vegas, and L. Gilbert provided critical field and logistical support. P. Meyers, I. Perfecto, G. Paoli, and G. Murray provided comments on the manuscript. Trail system development and lab facilities at CNP were funded by NSF BSR-8315399, UT Austin's Institute for Latin American Studies Mellon grants program, and WWF. Financial support to E. DeMattia was from The Sophie Danforth Conservation Biology Fund, Rackham Graduate School at the University of Michigan (UM), The Latin and Caribbean Studies Department (UM), and the Department of Ecology and Evolutionary Biology (UM).

\section{LITERATURE CITED}

Adler, G. H., AND D. W. KesTell. 1998. Fates of Neotropical tree seeds influenced by spiny rats (Proechimys semispinosus). Biotropica 30: 677681.

, AND J. O. SEAmon. 1991. Distribution and abundance of a tropical rodent, the spiny rat, on islands in Panama. J. Trop. Ecol. 7: 349-360.

Altrichter, M., E. Carrillo, J. Saenz, and T. K. Fuller. 2001. Whitelipped peccary (Tayassu pecari, Artiodactyla: Tayassuidae) diet and fruit availability in a Costa Rican rain forest. Rev. Biol. Trop. 49: 1183-1192.

Asquith, N., S. Wright, AND M. Clauss. 1997. Does mammal community composition control recruitment in Neotropical forests? Evidence from Panama. Ecology 78: 941-946.

Asquith, N. M., J. Terborgh, A. E. Arnold, And C. M. Riveros. 1999. The fruits the agouti ate: Hymenaea courbaril seed fate when its disperser is absent. J. Trop. Ecol. 15: 229-235.

BREWER, S. W., AND M. A. H. WeBB. 2001. Ignorant seed predators and factors affecting the seed survival of a tropical palm. Oikos 93: 32-41.

CARRILlO, E., G. WONG, AND A. CUARÓN. 2000. Monitoring mammal populations in Costa Rican protected areas under different hunting restrictions. Conserv. Biol. 14: 1580-1591.

CraWley, M. J. 2000. Seed predators and plant population dynamics. In M. Feener (Ed.). Seeds: The ecology of regeneration in plant communities, pp. 157-192. CABI International, Wallingford.

DeMatTiA, E. A. 2004. Effects of small rodents and large mammals on seed predation and seedling regeneration within primary and secondary Costa Rican forests. Ph.D. Dissertation, University of Michigan, Ann Arbor.

_ L. M. CURRAN, AND B. J. RATHCKE. 2004. Effects of small rodents and large mammals on tropical seeds. Ecology 85: 2161-2170.

DeSTEVEn, D., AND F. PUTZ. 1984. Impact of mammals on early recruitment of a tropical canopy tree, Dipteryx panamensis, in Panama. Oikos 43: 207-216.

FLEMING, T. H. 1970. Notes on the rodent faunas of two Panamanian forests. J. Mammal. 51: 473-490.

1973. The number of rodent species in two Costa Rican forests. J Mammal. 54: 518-521.

FORGET, P. 1993. Post-dispersal predation and scatterhoarding of Dipteryx panamensis seeds by rodents in Panama. Oecologia 94: 255-261.

. 1994. Recruitment pattern of Voucapoua americana (Caesalpiniaceae), a rodent-dispersed tree species in French Guiana. Biotropica 26: 408-419.

Forget, P. M., K. Kitajima, AND R. B. Foster. 1999. Pre- and post-dispersal seed predation in Tachigali versicolor (Caesalpiniaceae): Effects of timing and fruiting variation among trees. J. Trop. Ecol. 15: 61-81.
Guariguata, M. R., H. Arias-LeClaire, and G. Jones. 2002. Tree seed fate in a logged and fragmented forest landscape, Northeastern Costa Rica. Biotropica 34: 405-415.

Hammond, D. S. 1995. Post-dispersal seed and seedling mortality of tropical dry forest trees after shifting agriculture, Chiapas, Mexico. J. Trop. Ecol. 11: 295-313.

Harms, K. E., S. J. Wright, O. Calderón, A. Hernández, and E. A. Herre. 2000. Pervasive density-dependent recruitment enhances seedling diversity in a tropical forest. Nature 404: 493-495.

Hartshorn, G. S. 1983. Wildlands conservation in Central America. In S. L. Sutton, T. C. Whitmore, and A. C. Chadwick (Eds.). Tropical rain forests: Ecology and management, pp. 423-444. Blackwell Scientific Publishers, Oxford.

Hubbell, S. P., R. B. Foster, S. T. O’Brien, K. E. Harms, R. Condit, B. WeChSLER, S. J. Wright, aNd S. L. DE LAO. 1999. Light-cap disturbances, recruitment limitation, and tree diversity in a Neotropical forest. Science 283: 554-557.

JANZEN, D. 1971. Seed predation by animals. Annu. Rev. Ecol. Syst. 2: 465-492. Jerozolimski, A., AND C. A. Peres. 2003. Bringing home the biggest bacon: A cross-site analysis of the structure of hunter-kill profiles in Neotropical forests. Biol. Conserv. 11: 415-425.

LAMBERT, T., AND G. ADLER. 2000. Microhabitat use by a tropical forest rodent, Proechimys semispinosus, in Central America. J. Mammal. 81: 70-76.

Naughton-Treves, L., J. L. Mena, A. Treves, N. Alvarez, and V. C. RadeLOFF. 2003. Wildlife survival beyond park boundaries: The impact of slash-burn agriculture and hunting on mammals in Tambopata, Peru. Conserv. Biol. 17: 1106-1117.

Notman, E., D. L. Gorchov, And F. Cornejo. 1996. Effect of distance, aggregation, and habitat on levels of seed predation for two mammalsdispersed Neotropical rain forest tree species. Oecologia 106: 221-227.

Peres, C. A. 2001. Synergistic effects of subsistence hunting and habitat fragmentation on Amazonian forest vertebrates. Conserv. Biol. 15: 14901505.

PHILLIPS, P. L. 1989. The relationship of successional and primary tropical forest to color infrared photography. Master's Dissertation, University of Texas at Austin, Austin.

REID, F. 1997. A field guide to the mammals of Central America and Southeast Mexico, 343 p. Oxford University Press, New York.

RICHARDS, P. W. 1952. The tropical rain forest, 575 p. Cambridge University Press, Cambridge.

RoldÁ, A. I., AND J. A. SimONETti. 2001. Plant-mammal interactions in tropical Bolivian forests with different hunting pressures. Conserv. Biol. 15: 617-623.

Silman, M. R., J. W. Terborgh, ANd R. A. Kiltie. 2003. Population regulation of a dominant rain forest tree by a major seed predator. Ecology 84: 431438.

SORK, V. 1987. Effects of predation and light on seedling establishment of Gustavia superba. Ecology 65: 1341-1350.

Terborgh, J. 1999. Requiem for nature, 234 p. Island Press, Washington, DC.

Voss, R. S., AND L. H. EMmONs. 1996. Mammalian diversity in Neotropical lowland forest: A preliminary assessment. Bull. Am. Mus. Nat. Hist. 230: $1-115$.

Wright, S. J., AND H. C. Duber. 2001. Poachers and forest fragmentation alter seed dispersal, seed survival, and seedling recruitment in the palm Attalea butyraceae with implications for tropical tree diversity. Biotropica 33: 583-595.

, H. Zeballos, I. Dominguez, M. M. Gallardo, M. C. Moreno, AND R. BANEZ. 2000. Poachers alter mammal abundance, seed dispersal, and seed predation in a Neotropical forest. Conserv. Biol. 14: 227-239. 